\title{
AGRESIVITAS DAN KONTROL DIRI \\ PADA REMAJA DI BANDA ACEH
}

Mohammad Arif Sentana

Program Studi Psikologi Fakultas Kedokteran Universitas Syiah Kuala

arifsentana@merahputih.id

Intan Dewi Kumala

Program Studi Psikologi Fakultas Kedokteran Universitas Syiah Kuala

\begin{abstract}
Abstrak
Meningkatnya kecenderungan kenakalan diantara remaja di Banda Aceh telah menjadi perhatian besar. Pola kenakalan remaja yang pada awalnya hanya berupa tawuran atau perkelahian antar pelajar semakin mengarah pada tindakan-tindakan yang tergolong kriminalitas seperti penganiayaan, penusukan, dan pemerkosaan. Kasus kenakalan remaja tersebut merupakan bentuk dari perilaku agresi yang disebabkan oleh kurangnya kontrol diri pada individu. Penelitian ini bertujuan untuk mengetahui hubungan antara agresivitas dan kontrol diri pada remaja di Banda Aceh. Agresivitas merupakan respon oleh individu yang memberikan hal tidak menyenangkan kepada orang lain. Sedangkan kontrol diri merupakan kemampuan individu untuk menentukan perilakunya berdasarkan standar tertentu seperti moral, nilai, dan aturan di masyarakat agar mengarah pada perilaku positif. Sampel pada penelitian ini berjumlah 270 remaja di Banda Aceh. Teknik pengambilan sampel menggunakan metode disproportional stratified random sampling. Hasil analisis data menggunakan teknik analisis data Pearson menunjukkan koefisien korelasi (r) sebesar $-0,448$ dengan nilai $\mathrm{p}=0,000(\mathrm{p}<0,05)$. Hipotesis yang diajukan diterima sehingga dapat disimpulkan bahwa terdapat hubungan negatif antara agresivitas dan kontrol diri pada remaja di Banda Aceh. Hal ini menunjukkan semakin tinggi kontrol diri maka semakin rendah agresivitas remaja di Banda Aceh. Remaja dengan tingkat kontrol diri yang tinggi akan mampu untuk mempertimbangkan konsekuensi dari perbuatan mereka dan dapat menghindari berperilaku agresif.
\end{abstract}

Kata Kunci: agresivitas, kontrol diri, remaja.

\begin{abstract}
The increasing tendency of delinquency among adolescents in Banda Aceh has become a major concern. Juvenile delinquency that at first merely brawling or fights between students, nowadays increasingly leads to actions that are classified as criminal acts such as torturing, stabbing, and raping. This case of juvenile delinquency is a form of aggression behavior caused by the lack of self-control in individuals. This study aims to investigate the correlation between aggression and self-control of adolescents in Banda Aceh. Aggression is a response by individuals to give unpleasant feeling to others. While self-control is the ability of individuals to determine their behavior based on moral standards, values, and rules in society aimed for a positive behavior. The sample in this study is 270 adolescents in Banda Aceh. Sampling techinique using disproportional stratified random sampling method. The data result is analysed using Pearson technique show the result $(r)=-0,448$ with value $\mathrm{p}=0,000(\mathrm{p}<0,5)$. The proposed hypothesis was confirmed so it can be concluded that there is a negative correlation between aggression and self-control in adolescents in Banda Aceh. This shows the higher level of self-control lead to lower level of aggression on adolescents in Banda Aceh. Adolescent with high self-control will be able to consider the consequences of their action and may avoid behaving aggressive.
\end{abstract}

Keywords: aggression, self-control, adolescent.

Meningkatnya kecenderungan kekerasan diantara remaja telah menjadi perhatian besar. Selama beberapa tahun terakhir ini, masalah kenakalan remaja telah menjadi salah satu masalah pokok yang dihadapi oleh sebagian besar masyarakat, terutama masyarakat yang tinggal di kota-kota besar (Badan Pusat Statistik, 2010). Lobey dan Hay (dalam Fasilita, 2012) mengatakan bahwa perilaku kenakalan remaja berubah tingkat dan polanya pada masa remaja dan masa dewasa awal. Pola kenakalan remaja yang pada awalnya hanya berupa tawuran atau perkelahian antar pelajar, saat ini semakin mengarah pada tindakan-tindakan yang tergolong sebagai tindak kriminalitas seperti pencurian, pemerkosaan, penculikan, bahkan pembunuhan (Badan Pusat Statistik, 2010).

Beberapa kasus kriminal di Banda Aceh dengan pelaku remaja yang didapat oleh peneliti dari media masa yang dilakukan oleh remaja adalah perkelahian yang berbuntut penusukan yang dilakukan oleh remaja usia 17 
tahun. Kejadian tersebut diketahui terjadi karena dipicu oleh rasa cemburu sehingga membuat remaja tersebut melabrak sekelompok remaja lainnya (Serambi, 2015). Kejadian penusukan juga terjadi pada tahun berikutnya. Personel dari Unit Kejahatan dan Kekerasan (Jatanras) Satuan Reskrim Polresta Banda Aceh menangkap enam remaja di warnet, mereka ditangkap setelah menikam dan menganiaya dua mahasiswa. Keenam remaja itu diketahui masih berstatus pelajar Sekolah Menengah Pertama (SMP) dan Sekolah Menengah Atas (SMA), dan dua diantaranya telah putus sekolah. Kejadian ini terjadi ketika para pelajar tersebut tidak terima dinasehati oleh kedua mahasiswa tersebut saat mereka sedang kebutkebutan di jalan raya (Serambi, 2016). Selain penusukan, juga terjadi kasus penculikan serta pemerkosaan dimana pelakunya adalah empat remaja dan pemuda berusia 19 hingga 26 tahun. Keempat pelaku ditangkap setelah menculik dan memperkosa seorang siswi SMP didalam sebuah mobil. Kejadian tersebut terjadi karena salah seorang pelaku ditolak cintanya oleh korban (Acehkita, 2016). Berdasarkan beberapa kasus di atas, dapat dikatakan bahwa penyebab terjadinya kejadian tersebut adalah permasalahan yang kecil dan dapat dihindari. Kasus yang disebutkan diatas merupakan bentuk perilaku agresi yang disebabkan oleh kurangnya kontrol diri pada individu.

Baron (dalam Diponegoro dan Malik, 2013) mengemukakan agresivitas adalah tingkah laku yang diarahkan dengan tujuan menyakiti makhluk hidup lain. Baron menambahkan bahwa perilaku agresi dapat dilakukan secara fisik maupun mental, dengan demikian dapat dilihat dan diamati, karena memiliki bentuk yang jelas, yaitu bentuk fisik pukulan, tendangan, dan verbal (cacian, hujatan, makian). Mundy (dalam Guswani dan Kawuryan, 2011) menyebutkan bahwa kemunculan perilaku agresivitas dapat disebabkan karena berhadapan dengan situasi-situasi atau keadaan yang tidak menyenangkan dalam lingkungannya. Agresivitas sering kali disebabkan oleh amarah, yang merupakan jembatan psikologis antara komponen perilaku dan komponen kognitif dalam agresivitas. Individu pada umumnya menjadi lebih agresif ketika sedang marah dibandingkan saat tidak marah (Buss dan Perry, 1992).

Krahe (2001) menyebutkan perilaku agresi yang muncul pada diri individu dapat dipengaruhi oleh faktor kepribadian yaitu kontrol diri, iritabilitas, kerentanan emosional, pikiran yang kacau, harga diri dan gaya atribusi permusuhan sedangkan faktor situsional yaitu adanya penyerangan, efek senjata, karakteristik target, alkohol dan temperatur udara. Guswani dan Kawuryan (2011) menyebutkan kontrol diri menjadi salah satu faktor pendukung untuk mengurangi perilaku agresi pada individu. Aroma dan Suminar (2012) mengatakan semakin tinggi tingkat kontrol diri maka semakin rendah pula kecenderungan perilaku kenakalan remaja. Sebaliknya, semakin rendah tingkat kontrol diri maka semakin tinggi kecenderungan perilaku kenakalan remajanya. Fasilita (2012) menambahkan semakin bertambah usia individu, semakin baik ia mengendalikan dirinya untuk menahan diri dalam melakukan perilaku kekerasan dan agresivitas. Ghufron dan Risnawati (dalam Auliya dan Nurwidawati, 2014) menyebutkan salah satu faktor kepribadian yang memengaruhi munculnya perilaku agresivitas yaitu kontrol diri.

Tangney, Baumiester, dan Boone (2004) menyebutkan kontrol diri merupakan kemampuan individu untuk menentukan perilakunya berdasarkan standar tertentu seperti moral, nilai, dan aturan di masyarakat agar mengarah pada perilaku positif. Goldfried dan Merbaum (dalam Fasilita, 2012) mendefinisikan kontrol diri sebagai satu kemampuan untuk menyusun, membimbing, mengatur dan mengarahkan bentuk perilaku yang dapat membawa individu kearah konsekuensi yang positif. Goldfied menambahkan kontrol diri yang lemah pada individu mengarahkan dirinya pada konsekuensi negatif, yang akan merugikan dirinya dan individu lain. Individu yang kurang dapat mengontrol dirinya dari dorongan-dorongan yang bersifat negatif, maka mereka dominan akan berperilaku agresif.

\section{PENGERTIAN AGRESIVITAS}

Agresivitas adalah keinginan untuk menyakiti individu lain, dengan cara mengekspresikan perasaan negatifnya seperti permusuhan untuk mencapai tujuan yang diinginkan (Buss dan Perry, 1992). Komponen agresivitas terdiri dari agresi fisik, agresi verbal, kemarahan, dan permusuhan (Buss dan Perry, 1992).

\section{PENGERTIAN KONTROL DIRI}

Kontrol diri adalah kemampuan individu untuk menentukan perilakunya berdasarkan standar tertentu seperti moral, nilai, dan aturan di masyarakat agar mengarah pada perilaku positif yang lebih menguntungkan individu (Tangney, Baumeister, dan Boone, 2004). Komponen kontrol diri terdiri dari disiplin diri, tindakan atau aksi yang tidak impulsif, pola hidup sehat, etika kerja, dan keandalan (Tangney dkk, 2004).

\section{HUBUNGAN ANTARA AGRESIVITAS DAN KONTROL DIRI PADA REMAJA}

Bandura (1971) beranggapan bahwa perilaku agresif merupakan sesuatu yang dipelajari dan bukannya perilaku yang dibawa individu sejak lahir. Bandura menambahkan bahwa ternyata anak-anak sejak usia dini dapat mempunyai perilaku agresi hanya dengan mengamati perilaku agresi sesosok model (orang tua, pengasuh, guru). Bandura (1971) menyatakan bahwa individu belajar banyak perilaku melalui peniruan, bahkan tanpa adanya penguatan (reinforcement) sekalipun yang individu terima. Individu dapat meniru beberapa perilaku hanya melalui pengamatan terhadap perilaku model, dan akibat yang ditimbulkannya atas model tersebut, termasuk agresi dan kontrol diri.

Baumeister, Vohs, dan Tice (2007) mengatakan kontrol diri merupakan proses yang berkembang pada individu melalui intervensi psikologis yang bahkan juga terjadi pada masa dewasa. Kontrol diri merupakan kemampuan yang dimiliki individu untuk mengubah respon individu tersebut secara sadar dan sengaja untuk 
membuat individu dapat menahan atau menghilangkan respon negatif dan mengubahnya menjadi respon lain yang lebih sesuai (Baumeister dkk, 2007). Saat respon negatif seperti perilaku agresif terjadi, individu dengan kontrol diri yang baik dapat dengan sengaja mengubah responnya untuk menghindari dirinya berperilaku agresif (Baumeister dkk, 2007).

Pada penelitian oleh Fasilita (2012) mengenai hubungan agresivitas dan kontrol diri, didapatkan semakin bertambahnya usia individu akan semakin memberikan kemampuan mengontrol diri dengan baik dan mengurangi berperilaku agresif. Calhoun dan Acocella (1990) juga menggatakan individu akan memiliki kemampuan kontrol diri yang baik seiring bertambahnya usia. DeWall, Finkel, dan Denson (2011) menambahkan, ketika dorongan untuk berbuat agresi mencapai puncaknya, kontrol diri dapat membantu remaja menurunkan agresi dengan mempertimbangkan aturan dan norma sosial yang ada di masyarakat.

DeWall dkk (2011) menyebutkan, dengan mengajak individu remaja untuk merubah dorongan agresinya terbukti dapat membantu dalam mengurangi konsekuensi negatif dari perilaku agresi antara individu, konsekuensi negatif ini bisa berbentuk luka fisik dari berkelahi, ekonomi, dan celaan dari lingkungan sosial. Remaja yang memiliki kontrol diri yang baik akan dapat menghindarkan dirinya dari konsekuensi negatif yang berasal dari perilaku agresi tidak terokontrol dan dapat menyesuaikan dirinya dengan norma yang ada di masyarakat (Denson, DeWall, dan Finkel, 2012).

\section{METODE}

Penelitian ini merupakan penelitian kuantitatif dengan jenis penelitian korelasi. Adapun populasi dalam penelitian ini yaitu remaja di Banda Aceh. Penentuan sampel pada penelitian ini menggunakan teknik disproportional stratified random sampling. Teknik disproportional stratified sampling digunakan untuk pengambilan setiap jumlah sampel yang dibagi secara tidak proporsional agar semua tingkatan yang berdasarkan usia dapat diambil menjadi sampel penelitian dalam penelitian ini. Pada random sampling, populasi diasumsikan homogen (mengandung satu ciri) sehingga sampel dapat diambil secara acak dan setiap subjek mempunyai peluang yang sama untuk dijadikan sampel penelitian (Idrus, 2009). Jumlah sampel yang ditentukan dalam penelitian ini sebanyak 270 responden. Adapun kriteria sampel pada penelitian ini adalah: a) Remaja berusia 15-19 tahun, b) Berada di Banda Aceh.

Metode pengumpulan data menggunakan skala psikologi yang diadaptasi, yaitu: Aggression Questionnaire yang disusun oleh Buss dan Perry (1992) berjumlah 29 aitem yang terdiri dari 5 pilihan jawaban yang didasari berdasarkan skala Likert, dan Self-Control Scale yang disusun oleh Tangney dkk (2004) berjumlah 36 aitem yang terdiri dari 5 pilihan jawaban yang didasari berdasarkan skala Likert.

\section{HASIL DAN PEMBAHASAN}

Subjek penelitian berada pada usia 15-19 tahun. Persentase subjek yang berusia 15 tahun sebanyak $11,48 \%$, usia 16 tahun sebanyak $28,15 \%$, usia 17 tahun sebanyak 47,78\%, usia 18 tahun sebanyak $10,37 \%$, dan usia 19 tahun sebanyak 2,22\%. Subjek penelitian dengan jenis kelamin laki-laki sebanyak $38,52 \%$ dan perempuan sebanyak $61,48 \%$.

Berdasarkan tingkatan kategorisasi agresivitas, terdapat $2,96 \%$ remaja berada pada kategori agresivitas tinggi, $81,48 \%$ remaja pada kategorisasi agresivitas sedang, dan $15,56 \%$ berada pada kategori agresivitas rendah remaja di kota Banda Aceh. Pada tingkatan kategorisasi kontrol diri, terdapat $7,4 \%$ remaja berada pada kategori kontrol diri tinggi, 92,6\% remaja pada kategorisasi kontrol diri sedang, dan $0,37 \%$ berada pada kategori kontrol diri rendah remaja di kota Banda Aceh.

Hasil uji asumsi menunjukkan bahwa data agresivitas dan kontrol diri berdistribusi normal. Hal tersebut dilihat dari hasil uji normalitas variabel agresivitas diperoleh nilai signifikansi $(\mathrm{p})=0,200>0,05$, dan hasil uji normalitas variabel kontrol diri diperoleh nilai signifikansi $(p)=0,200>0,05$. Hasil uji asumsi juga menunjukkan bahwa data pada penelitian ini linear. Hal tersebut dapat dilihat dari hasil uji linearitas yang menunjukkan nilai signifikansi $(p)=0,000<0,05$.

Hasil uji hipotesis menunjukkan nilai signifikansi (p) $=0,000<0,05$ dengan nilai koefisien korelasi $(r)=-0,448$ dan nilai R Square $(\mathrm{R} 2)=0,201$ yang berarti bahwa ada hubungan negatif antara agresivitas dan kontrol diri pada remaja di Banda Aceh, dengan sumbangan efektif kontrol diri terhadap agresivitas sebesar $20,1 \%$.

Penelitian ini dilakukan untuk mengetahui hubungan antara agresivitas dan kontrol diri pada remaja di Kota Banda Aceh. Hasil penelitian menunjukkan bahwa terdapat hubungan yang negatif antara agresivitas dan kontrol diri. Hubungan yang negatif tersebut menunjukkan bahwa semakin tinggi kontrol diri pada remaja maka akan semakin rendah pula agresivitas remaja. Hal tersebut dibuktikan dari hasil analisis pada hubungan agresivitas dan kontrol diri yang menunjukkan nilai signifikansi $(p)=0,000(p<0,05)$. Hasil tersebut menunjukkan bahwa hipotesis penelitian ini diterima.

Berdasarkan hasil penelitian yang telah dilakukan, menunjukkan bahwa kontrol diri yang tinggi pada remaja berkaitan dengan agresivitas yang rendah. Tinjauan antara agresi dan kontrol diri menunjukkan bahwa kontrol diri dapat berkontribusi untuk mengurangi bahaya psikologis, ekonomis, fisik, dan sosial yang berhubungan dengan agresi tak terkontrol (Denson, DeWall, dan Finkel, 2012). Tangney, Baumeister, dan Booner (2004) mengatakan semakin tinggi kontrol diri individu maka akan memberikan dampak positif bagi dirinya. Hal tersebut di karenakan kontrol diri mampu mengarahkan dan mengatur perilaku kearah yang lebih baik saat dihadapkan pada dorongan negatif. Ketika dorongan agresi terjadi, kontrol diri dapat membantu individu mengesampingkan keinginannya untuk bersikap agresif, dan mampu memberikan respon yang sesuai dengan norma pribadi atau sosial yang dapat meminimalisir 
perilaku agresi (DeWall, Finkel, dan Denson, 2011). Hasil penelitian ini memiliki kemiripan dengan penelitian oleh Auliya dan Nurwidawati (2014) dimana terdapat hubungan negatif antara kontrol diri dan agresivitas. Kontrol diri yang tinggi dapat membantu mengurangi kecenderungan perilaku agresif pada remaja (Aroma dan Suminar, 2012). Remaja yang memiliki perilaku agresi yang rendah disebutkan memiliki kematangan emosi yang tinggi sehingga dapat mengontrol diri dengan baik (Guswani dan Kawuryan, 2011).

Berdasarkan pengelompokan kategorisasi agresivitas dalam penelitian pada remaja kota Banda Aceh ini maka, didapatkan 2,96\% remaja berada pada kategori tinggi, $81,48 \%$ remaja pada kategorisasi sedang, dan $15,56 \%$ berada pada kategori rendah. Hasil tersebut mengindikasikan sebagian besar remaja dalam penelitian ini memiliki tingkat agresivitas yang cenderung rendah. Buss dan Perry (1992) mengatakan semakin tinggi agresivitas yang dimiliki individu, maka individu tersebut akan memiliki intensitas dan frekuensi berperilaku agresif yang tinggi, seperti lebih sering untuk menghujat, berkelahi, bermusuhan, dan juga marah, sedangkan individu yang memiliki tingkat agresivitas rendah akan lebih jarang untuk berperilaku agresif. Dengan begitu dapat disebutkan sebagian besar remaja di Banda Aceh merupakan remaja yang dapat mengendalikan dorongan negatif untuk berpilaku agresif.

Pada pengelompokan kategorisasi kontrol diri dalam penelitian ini, didapatkan $7,4 \%$ remaja berada pada kategori tinggi, 92,6\% remaja pada kategorisasi sedang, dan $0,37 \%$ remaja pada kategori rendah. Hasil tersebut mengindikasikan sebagian besar remaja dalam penelitian ini memiliki tingkat kontrol diri yang cenderung tinggi. Tangney dkk (2004) menyebutkan individu yang memiliki kontrol diri yang tinggi akan mampu memberikan performansi yang baik dalam bekerja dan akademis, dimana individu yang memiliki kontrol diri yang rendah akan cenderung untuk menunda pekerjaan dan memberikan performa yang buruk. Individu yang memiliki kontrol diri yang baik akan dapat mengendalikan dorongan impulsif pada diri mereka dalam bertindak, mereka juga akan dapat berinteraksi dan memiliki hubungan interpersonal yang baik dibandingkan mereka yang memiliki kekurangan didalam mengontrol diri. Dengan begitu dapat disebutkan sebagian besar remaja di Banda Aceh merupakan remaja yang dapat mengontrol diri mereka dalam kehidupan sehari-hari dan juga dapat dengan matang memikirkan konsekuensi dari perbuatan mereka.

Berdasarkan hasil analisa measures of association, ditemukan nilai koefisien determinasi agresivitas dan kontrol diri pada remaja sebesar 0,201 atau 20,1\%, hasil ini mengindikasikan kontrol diri mempengaruhi remaja dalam berperilaku agresif sebesar 20,1\%. Hasil ini sejalan dengan penelitian Auliya dan Nurwidawati (2014) yang menyatakan bahwa agresivitas berhubungan dengan kontrol diri. Hasil tersebut diartikan jika variabel kontrol diri rendah, maka perilaku agresi akan tinggi. Sebaliknya jika kontrol diri tinggi maka perilaku agresinya rendah. Sementara sebesar $79,9 \%$ yang mempengaruhi agresivitas dan kontrol diri pada remaja adalah faktor diluar variabel kontrol diri. Aroma dan Suminar (2012) menyebutkan faktor lain yang mempengaruhi hubungan antara agresivitas dan kontrol diri ini adalah lingkungan, keluarga, dan ekonomi. Guswani dan Kawuryan (2011) menyebutkan pengaruh lainnya adalah religiusitas, kecerdasan emosional, pengaruh media, dan kematangan emosi.

Peneliti menyadari akan adanya kekurangan pada penelitian ini. Baron dan Byrne (2005) menyebutkan salah satu faktor yang menyebabkan agresivitas adalah faktor kepribadian. Calhoun dan Acocella (1990) juga menyebutkan salah satu faktor yang mempengaruhi kontrol diri adalah kepribadian dan etnis. Pada penelitian ini, peneliti tidak terlalu memperhatikan dan mengulas lebih mendalam mengenai faktor kepribadian dan juga etnis remaja yang merupakan subjek pada penelitian ini, sehingga penelitian ini hanya melihat hubungan antara agresivitas dan kontrol diri pada remaja secara umum saja. Kekurangan ini dapat menjadi pertimbangan oleh peneliti selanjutnya yang ingin melaksanakan penelitian lanjutan dengan tema yang sama.

\section{PENUTUP}

Berdasarkan hasil peneltian, dapat disimpulkan bahwa hipotesis penelitian ini diterima yaitu terdapat hubungan antara agresivitas dan kontrol diri pada remaja di Banda Aceh. Hasil penelitian menunjukkan bahwa terdapat hubungan yang negatif diantara agresivitas dan kontrol diri pada remaja di Banda Aceh. Hubungan negatif tersebut menunjukkan bahwa semakin tinggi tingkat kontrol diri pada remaja semakin rendah tingkat agresivitasnya, dan juga sebaliknya semakin rendah tingkat kontrol diri pada remaja semakin tinggi tingkat agresivitasnya. Remaja dengan tingkat kontrol diri yang tinggi akan mampu untuk mempertimbangkan konsekuensi dari perbuatan mereka dan dapat menghindari berperilaku agresif. Pada penelitian ini pada tingkatan agresivitas ditemukan bahwa sebagian besar remaja berada pada tingkatan agresivitas rendah, sementara pada tingkatan kontrol diri ditemukan sebagian besar remaja berada pada tingkatan kontrol diri tinggi.

Adapun saran bagi peneliti selanjutnya diharapkan dapat melibatkan subjek penelitian lain seperti pada guru yang mendidik remaja secara langsung. Peneliti juga menganjurkan penelitian selanjutnya menggunakan metode kualitatif. Variabel agresivitas dan kontrol diri juga dapat dikaji dengan variabel lain seperti konformitas, religiusitas, narsistik, kepribadian, etnis serta berbagai variabel lainnya.

\section{DAFTAR RUJUKAN}

Acehkita. 2016, Mei 12. Duh, Siswi SMP Diperkosa 4 Pria. Acehkita. Diambil dari http://acehkita.com/duhsiswi-smp-diperkosa-4-pria/ diakses pada 4 Agustus 2016 
Aroma, I. S. \& Suminar, D. R. 2012. Hubungan Antara Tingkat Kontrol Diri Dengan Kecenderungan Perilaku Kenakalan Remaja. Jurnal Psikologi Pendidikan dan Perkembangan 1(2), 1-6

Auliya, M. \& Nurwidawati, D. 2014. Hubungan Kontrol Diri Dengan Perilaku Agresi Pada Siswa Sma Negeri 1 Padangan Bojonegoro. Character 2(3), 1-6

Badan Pusat Statistik. 2010. Profil Kriminalitas Remaja 2010. Jakarta: Indonesia

Bandura, A. 1971. Social Learning Theory. New York: General Learning Press.

Baron, R. A., \& Byrne, D. 2005. Psikologi Sosial. Edisi 10. Jakarta. Erlangga.

Baumeister, R. F., Vohs, K. D., dan Tice, D. M. 2007. The Strength Model of Self-Control. Association for Psychological Science 16(6), 351-355

Buss, A. H. \& Perry, M. 1992. The Aggression Questionnaire. Journal of Personality and Social Psychology 63(3), 452-459

Calhoun, J. F. \& Acocella, J. R. 1990. Psychology of Adjustment and Human Relationship. New York: McGraw Hill, Inc.

Denson, T. F., DeWall, C. N. \& Finkel, E. J. 2012. SelfControl and Aggression. Psychological Science 21(1), 20-25

DeWall, C. N., Finkel, E. J., \& Denson, T. F. 2011. SelfControl inhhibits Aggression. Social and Personality Psychology Compass 5(7), 458-472

Diponegoro, A. \& Malik, M. A. 2013. Hubungan Pola Asuh Otoritatif, Kontrol Diri, Ketrampilan Komunikasi dengan, Agresivitas Siswa Kelas X SMA $N 4$ Yogyakarta. Jurnal Bimbingan dan Konseling "PSIKOPEDAGOGIA" 2(2), 342-366

Fasilita, D. A. 2012. Kontrol Diri Terhadap Perilaku Agresif Ditinjau Dari Usia Satpol Pp Kota Semarang. Journal of Social and Industrial Psychology 1(2), 3440

Guswani, A. M. \& Kawuryan, F. 2011. Perilaku Agresi Pada Mahasiswa Ditinjau Dari Kematangan Emosi. Jurnal Psikologi Pitutur 1(2), 86-92

Idrus, M. 2009. Metode penelitian ilmu sosial. Jakarta: Erlangga

Krahe, B. 2001. The Social Psychology of Aggression. East Sussex: Psychology Press

Serambi. 2015, Juli 29. Perangai Remaja Aceh Sudah Parah. Serambi Indonesia. Diambil dari http://aceh.tribunnews.com/2015/07/29/perangairemaja-aceh-sudah-parah diakses pada 4 Agustus 2016

Serambi. 2016, April 4. Tikam Mahasiswa, Enam Remaja Ditangkap di Warnet. Serambinews Indonesia. Diambil http://aceh.tribunnews.com/2016/04/04/tikammahasiswa-enam-remaja-ditangkap-di-warnet diakses pada 4 Agustus 2016

Tangney, J. P., Baumiester, R. F., \& Boone, A. L. 2004. High Self Control Predicts Good Adjusment, Less Pathology, Better Grades, and Interpersonal Success. Journal of Personality.72 (2), 271-322. 